\title{
WORLD RED CROSS DAY
}

World Red Cross Day, 8 May, was commemorated by radio and television in many countries. The broadcasts, registered in French, English, German, Spanish and Arabic and intended for all five continents, as in previous years were to mark the anniversary of Henry Dunant's birth.

A broadcast on the Swiss French-speaking radio was given by the producer and commentator Jean Martel and several Red Cross personalities. The League's fifty years of activity was the subject for Mr. Gazay, that institute's Director of Information, Mr. Beer, Secretary-General, and Mr. J. P. Robert-Tissot, Director of the Relief Bureau, illustrating the theme of World Red Cross Day; In a Changing World, Red Cross Stands for Tomorrow. Then Mr. R. Cassin, Nobel Peace Prize winner, explained the importance and place of our movement and its ideal in contemporary ethics. In conclusion, Mr. J. Freymond, Acting President of the ICRC, stressed how necessary in a troubled world was respect for the Geneva Conventions.

Part or all of the programme was sent to various broadcasting stations and to many National Societies.

In a statement broadcast by the Swiss French-speaking television service, Mr. Freymond also explained the significance of the solidarity uniting millions of members of the Red Cross, Red Crescent and Red Lion and Sun at this time in history when humanitarian problems arise on an ever greater scale.

The Austrian, Bavarian and Swiss-German radios broadcast a programme entitled " Das Rote Kreuz wird nicht arbeitslos”.

In the morning of 8 May, at the Henry Dunant Monument in Geneva, there was a ceremony organized by the Geneva Section of the Swiss Red Cross. The ICRC was represented by Mr. J. Pictet, a Member and its Director-General. Mr. J. P. Buensod, President of the Geneva Section, and Mr. H. Beer, League Secretary General, addressed the audience. They showed that Dunant's ideal, evident in so many Red Cross achievements since 1863 and in the League's very existence for half a century, is perennial. 